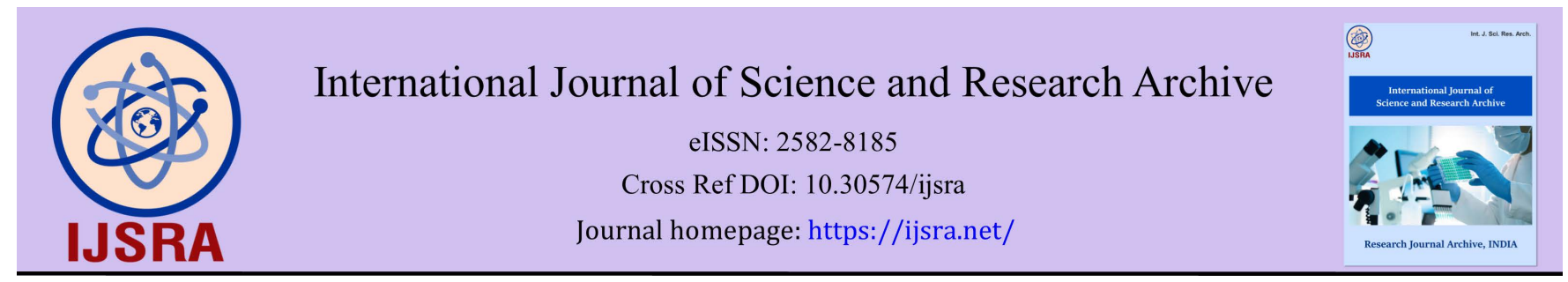

(REVIEW ARTiCle)

\title{
Towards sustainability of ecosystem services in North-East Nigeria
}

\author{
Justus Eronmosele Omijeh * \\ Department of Forestry and Wild life Management, Modibbo Adama University of Technology, Yola, Adamawa State, \\ Nigeria.
}

International Journal of Science and Research Archive, 2021, 02(02), 037-056

Publication history: Received on 08 February 2021; revised on 12 March 2021; accepted on 14 March 2021

Article DOI: https://doi.org/10.30574/ijsra.2021.2.2.0039

\begin{abstract}
Ecosystem services are the very essence of the inhabitants of the North-East Region of Nigeria; hence the sustainability of these services is very important. The concept of sustainability is imprecise and reveals two main underlying issues which are intergenerational fairness and the moral responsibility of the current generation to its descendants on the one hand, and the role of assets provided by nature including forest and marine ecosystems in satisfying both current interests and the obligations we assume to the future on the other. Many benefits from ecosystem services accrue to the six states of Adamawa, Gombe, Taraba, Yobe, Bauchi and Borno in the North-East Region of Nigeria. The economic value of Hadejia-Nguru wetlands which forms part of the Kamadougou-Yobe River Basin of the Lake Chad Basin was estimated at over US\$16 million per year. The estimated value of ecosystem services that can be attributed to inland watersheds and wetlands range between US\$5000 and US $\$ 100,000$ per hectare while coastal watersheds and wetlands were between US $\$ 500$ and US $\$ 1,000,000$ per hectare in 2007. The product of the national average of 0.284 tonnes/person/year of fuel wood consumption and number of inhabitants of 24,051,418 (2006 census projected to 2014) gave an estimated consumption of 6,830,603 tonnes/person/year for the six North-Eastern States. However, there are threats to the sustenance of ecosystem services, some of which include urbanization, progressive industrialization, overgrazing, exploitation of natural resources, depletion of wetlands, watersheds and insurgencies which have drastically reduced production of and accessibility to ecosystem services. These threats can be mitigated through development of framework for assessing demand and supply of these services, restoration of terrestrial and marine ecosystems through biodiversity approach, capacity building and forestry extension services to create awareness among the populace on the importance and value of ecosystem services.
\end{abstract}

Keywords: Ecosystem Services; Threats; Mitigation; Imperiled; Sustainability; Forestry Extension.

\section{Introduction}

Ecosystem services which include provisioning (food, water, timber, fibre) regulating (carbon sequestration, biological pest control, floods, diseases, wastes and water quality), cultural (recreational, aesthetic and spiritual benefits) and supporting (soil formation, photosynthesis and nutrient cycling), are the very essence of survival of most inhabitants of North East Nigeria [1], [2], [3]. Characteristically, this region, experiences diminishing biomass and wide-ranging ecosystems degradation, bush burning, induced by advancement of cultivation, grazing and population pressures that have led to extensification/intensification of cultivation resulting in the contraction and restriction of space and options available to pastoral activities [4]. TEEB, 2010 [5], estimated the monetary values of some regulatory ecosystem services for tropical ecosystems; the value of just four services for Nigeria's 92,376,800 hectares stood over N98trillion/year(\$1=N200). Between 2000 and 2010, an increase in Total Ecosystem Services Value (ESV) in Nigeria rose from N665.93 billion (2007US\$) to N667.44billion (2007US\$), 97.38\% of which was contributed by cultivated land [6]. The value of provisioning services increased, while regulation, support, recreation and culture services decreased

${ }^{*}$ Corresponding author: Justus Eronmosele Omijeh

Modibbo Adama University of Technology, Yola, Adamawa State, Nigeria.

Copyright (c) 2021 Author(s) retain the copyright of this article. This article is published under the terms of the Creative Commons Attribution Liscense 4.0. 
amongst which water regulation (-11.01\%), gas regulation (-7.13\%), cultural (-4.84\%) and climate regulation (-4.3\%) ecosystem functions are estimated as the most impacted [7]. The increase in the Total Ecosystem Value (ESV) in Nigeria associated with the huge increase in ecosystem services due to cultivated land expansion may make land use changes (i.e., the ever-increasing agricultural expansion in Nigeria (Northeast inclusive) appear economically profitable [8]. Continuous loss of services such as climate and water regulation that are provided by the natural ecosystems can result in huge economic losses that may exceed the apparent gains from cultivated land development [9]. However, there is need to determine the ratio between demand and supply of ecosystem services in Northeast Nigeria. It is necessary to develop a framework for assessing the thresholds for ecosystem services to be able to know when they are imperiled following the suggestion of [10].

The objectives of this paper are to highlight the availability of ecosystem services in North-East Nigeria, the benefits that accrue to the inhabitants through these services, the major threats to the supply and demand of ecosystem services, the approaches to mitigate these threats.

\section{Study area}

The North East Nigeria has a total landmass of about 279,203km2 situated within Latitudes $6030^{\prime} \mathrm{N}$ to $14000^{\prime} \mathrm{N}$ and Longitude $8030^{\prime} \mathrm{E}$ to $15000^{\prime} \mathrm{E}$ and a total population of 18,971,965 (according to the 2006 census returns and 24,051,418 if projected to mid-2014) [11]. These figures are distributed among the six states of Adamawa, Bauchi, Borno, Gombe, Taraba and Yobe as follows (Table 1).

Table 1 Distribution of Land Mass and Population among six North-Eastern States (\%)

\begin{tabular}{|l|l|l|l|}
\hline S/n & State & Landmass (\%) & Population (\%) \\
\hline 1 & Adamawa & 12.61 & 16.64 \\
\hline 2 & Bauchi & 22.07 & 24.64 \\
\hline 3 & Borno & 24.31 & 21.88 \\
\hline 4 & Gombe & 6.31 & 12.40 \\
\hline 5 & Taraba & 19.11 & 12.13 \\
\hline 6 & Yobe Source: Tukur and Barde (2013). \\
\hline \multicolumn{4}{|c|}{} \\
\hline
\end{tabular}

The environment is dynamic, complex and responds to the interactions of the biotic and abiotic components in providing services that support life, the continuity or sustainability of ecosystem functions [12], but the nexus of deforestation, anthropogenic activities and climatic variability is taking its toll on this region [13].

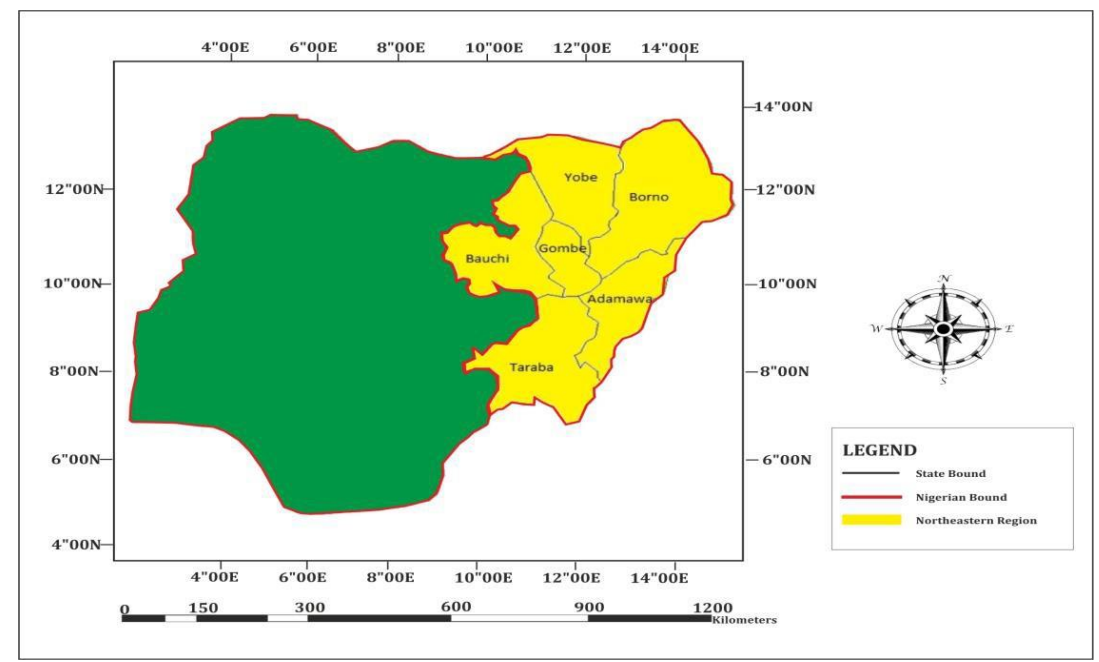

Figure 1 The Northeast Region 


\section{Previous work and methodology}

Secondary data were used in the literature review in writing this article. Desk research was conducted in deriving data from relevant agencies such as International Union of Forestry Organizations (IUFRO), Food and Agricultural Organization (FAO), United Nations Conference on Climate Change and Desertification (UNCCD), International Union on Conservation of Nature (IUCN), United Nations Development Programme (UNDP), World Food Programme (WFP), Nigeria Centre for Disease Control (NCDC), Afforestation Programme Co-ordinating Unit (APCU), World Bank Project, Forest Management Evaluation and Co-ordinating Unit (FORMECU), National Bureau of Statistics (NBS), National Population Commission (NPC), International Programme on Climate Change (IPCC), Also, consulted were relevant proceedings on international workshops, international journals and personal interface with relevant stakeholders on the subject matter. Microsoft Excel was used in some basic calculations.

\subsection{Integrated ecosystem services and land use practices}

Inkom et. al., 2017 [14], developed a framework for integrating ecosystem services into modern land use practices using content analysis to search for ecosystem keywords in land use planning policies and act (LUPPA) and to identify existing approaches for mainstreaming the ecosystem discovered. The authors discovered that major planning policy documents focused on planning for infrastructural development with less emphasis on environmental sustainability. This position could have effect on the demand and supply of ecosystem services.

\subsection{Human perception of ecosystem services}

Gouwakinnou et. al., 2019 [15], studied and highlighted the perception of inhabitants surrounding two forest reserves, (Alibori-superiour and Ouenon), about the importance of ecosystem services provided to them. They suggested that political-decision making by policy makers should understand biophysical processes involved in determining ecosystem services.

\subsection{Role of agencies in ecosystem services assessment}

Some agencies, United States Agency International Development (USAID), Mercy Corps, Action against hunger, Cooperazione Internazionale, Catholic relief services, International Rescue Committee, OXFAM, carried out an assessment of North East Nigeria joint livelihood and market recovery which was conducted between January and August, 2017. Field level qualitative interviews and quantitative enumerator led surveys were carried out in conjunction with high level decision makers in Maiduguri (capital of Borno state) and Abuja (federal capital of Nigeria). Across Borno, Yobe and Adamawa states. They did a nationwide assessment of China by quantifying the provision of threatened species habitat and four key regulating services-water retention, soil retention, sand storm prevention and carbon sequestration-in nature reserves which are the primary category of protected areas in China. They observed that China's nature reserves did not serve moderately well for key regulating ecosystem services. Nature reserves encompass only $10.2-12.5 \%$ of the source areas for the four key regulating services.

\subsection{Climate change, productivity and ecosystem services}

The relationship between climate change and productivity and by implication demand and supply of ecosystem services is expressed by Girardin et al.,2008 [16]; Le Bauer and Treseder,2008 [17]; McMillan et al.,2008[18]; Ollinger et al.,2008[19]; Phillips et al., 2008[20]; Reich and Oleksyn 2008 [21]; Saigusa et. al.,2008 [22] and Clark et. al.,2003 [23]. According to these authors, productivity as a result of climate change varies with geographic area, species stand composition, tree age, soils (water holding capacity) and effects of $\mathrm{CO}_{2}$ and nitrogen fertilization and interactions between any of these factors.

\subsection{Temperature, forest storage and carbon sequestration}

Increasing temperatures, longer dry seasons and increasing $\mathrm{CO}_{2}$ concentrations in the atmosphere in the long term, are expected to reduce the capacity of forests to store and sequester carbon possibly converting forests from carbon sinks to carbon sources [24]; [25]; [26] and [27]. Postel and Thompson, 2005 [28], recognized the contribution of forests to water and soil protection, hence the role of water regulation and soil protection may become increasingly important under climate change conditions

\subsection{Socio-economic benefits and ecosystem services.}

Some multiple socio-economic benefits such as expected global increase in wood production which may lower prices thereby benefitting consumers; the combination of lower prices and regionally diffentiated effects on productivity will cause differentiated effects on productivity on timber harvest related income and employment [29]. Harvests of Non 
Wood Forest Products (NWFP) have three major functions: provision of part of the daily necessities of forest dependent people, off-farm income and a safety net in times of adverse conditions for agricultural production [30]. It is also suggested by Osman- Elasha et. al., 2009 [31], that climate change will have impacts on the productivity of NWFPs and that their users will largely be impacted through increased pressure on forest products from people that look for emergency supplies or alternative ways of income.

\subsection{Climate change and recreational forestry}

The impact of climate change on cultural and recreational services of forests have been little studied and difficult to measure [32], but it is reported in some studies on recreational services such as skiing in mountainous areas where skiing at lower altitudes is likely to be affected by temperature increases [33]. The effect of climate change on forest biodiversity and structure in Africa and subsequent effect on attractiveness for tourists of many of the national parks need to be further studied.

\subsection{Management of biodiversity species for Ecosystem services in North Africa}

Countries in North Africa and Near East identified a number of associated biodiversity species that are actively managed for the ecosystem services related to food production, nutrition and sanitation (Table 2). Associated biodiversity species most frequently reported to be actively managed for the provision of ecosystem services in production system in the near east and North Africa.

Table 2 Biodiversity species managed for ecosystem services in North Africa

\begin{tabular}{|l|l|}
\hline Ecosystem services & List of species \\
\hline Pollination & $\begin{array}{l}\text { Honey bees: } \\
\text { European honey bee (Apis mellifera) Local honeybees } \\
\text { Bumble bees Wild bees } \\
\text { Wild butterflies }\end{array}$ \\
\hline $\begin{array}{l}\text { Pest and diseases } \\
\text { regulation }\end{array}$ & $\begin{array}{l}\text { Biological control organisms Fungi } \\
\text { Arbscular mycorrhizal fungi Invertebrates } \\
\text { Insects: } \\
\text { Eulophid wasp (Aphelinus mali) Chalid wasp (Aphytis melinus) Encyrtid wasp } \\
\text { (Capidosoma koehleri) Mealybug ladybird (Cryptolaemus spp) } \\
\text { Water hyacinth weevil (Neochetina eichhorniae) } \\
\text { Tomato mirid (Nesidiocoris termis) Parasitic wasps: } \\
\text { Anagyrus dactylopii Anagyrus indicus Bracon concoloran Arachnids: } \\
\text { Phytoseiid mite (Amblyseius idaeus) Plants: } \\
\text { Cabbage (Brassica oleraceae) Sunflower (Helianthus annuus) Mexican marigold } \\
\text { (Tagetes erecta) Trees: } \\
\text { Acacia nilotica Azadirachta indica (neem) } \\
\text { Balanites aegyptiaca (desert date) Eucalyptus oblique(messmate Senegalia senegal } \\
\text { Planting disease-resistant crop varieties Cicer arietinum(chickpea) } \\
\text { Cucurbita pepo (pumpkin) Lycopersicon escullentum(tomato) Function not specified }\end{array}$ \\
$\begin{array}{l}\text { Plants } \\
\text { Cedrus libani (cedar) } \\
\text { Hordeum spontaneum, H. vulgare (barley) Solanium elagnifolium (silverleaf } \\
\text { nightshade) Pests and pathogens } \\
\text { Bactrocera oleae (olive fruit fly) } \\
\text { Ceratitis capitata (Mediterranean fruitfly) Cydia pomonella (codling moth) } \\
\text { Eurygaster integriceps (shield bug) Eurygaster Maura (European tortoise bug) } \\
\text { Lobesia botrana (European grapevine moth) Prays citri (moth) }\end{array}$ \\
\hline
\end{tabular}




\begin{tabular}{|c|c|}
\hline & $\begin{array}{l}\text { Rhynchophorus ferrugineus (red palm weevil) Spilocaea oleaginea (fungal plant } \\
\text { pathogen Ticks } \\
\text { Tuta absoluta (moth) } \\
\text { Zeuzera pyrina (leopard moth) }\end{array}$ \\
\hline $\begin{array}{l}\text { Water purification and } \\
\text { waste management }\end{array}$ & $\begin{array}{l}\text { Trees Moringa (Moringa spp) Olive(olea spp) Poplar (Populous spp) } \\
\text { Aspen (Populous tremula) Other plants } \\
\text { Field crops Forage legumes } \\
\text { Common reed (Phragmites australis) Sorghum halepense (Johnson grass) } \\
\text { Sparganium erectum (simplestem bur-reed) }\end{array}$ \\
\hline Natural hazard regulation & $\begin{array}{l}\text { Planting crops and trees } \\
\text { Saltbush (Atriplex spp), Saltwort (Salsosa spp), and cover crops such as barley (for } \\
\text { soil erosion and salinity tolerance) } \\
\text { Mediterranean cypress (Cupressus simper virens) and carob tree (Certonia } \\
\text { siliqua) around forests for fire control. } \\
\text { Mediterranean saltbush (Atriplex haimus) Grey mangrove (Avicennia marina) } \\
\text { Common juniper (Juniperus communis) Date palm (Phoenix dactylifera) and carob } \\
\text { tree (Certonia siliqua) around forests for fire control. } \\
\text { Mediterranean saltbush (Atriplex haimus) Grey mangrove (Avicennia marina) } \\
\text { Common juniper (Juniperus communis) Date palm (Phoenix dactylifera) }\end{array}$ \\
\hline Nutrient cycling & $\begin{array}{l}\text { Planting crops and cover crops Chickpea (Cicer arieatinum) Lentil (Lens culinaris) } \\
\text { Alfalfa (Medicago sativa) Pea (Pisum sativum) Ervil (Vicia ervilia) } \\
\text { Vetch (Vicia sativa). }\end{array}$ \\
\hline $\begin{array}{l}\text { Soil formation } \\
\text { protection }\end{array}$ & $\begin{array}{l}\text { Acacia (Acacia spp) } \\
\text { Mangrove grass (Aeluropus lagopoides) Mediterranean saltbrush (Atriplex halimus) } \\
\text { Cadaba rotundifolia } \\
\text { Ceratonia spp } \\
\text { White saxaul(Haloxylon persicum) Odyssea mucronata } \\
\text { Cactus (Opuntia spp) } \\
\text { Desert bunchgrass (Panicum turgidum) Bulbous bluegrass (Poa bulbosa) Mesquite } \\
\text { (Prosopis juliflora) } \\
\text { Bridal broom (Retama monosperma) Saltwort (Salsola spp) } \\
\text { Arabian tamarisk (Tamarix Arabica) }\end{array}$ \\
\hline Water cycling & $\begin{array}{l}\text { Mediterranean saltbush (Atriplex halimus) Bulbous bluegrass (Poa balbosa) Saltwort } \\
\text { (Salsola spp) }\end{array}$ \\
\hline Habitat provisioning & $\begin{array}{l}\text { Acacia(Acacia spp) } \\
\text { Chickpea (Cicer spp) } \\
\text { Carob tree (Ceratonia siliqua) Dipterygium glaucum Lentil (Lens spp) Alfalfa } \\
\text { (Medicago sativa) Persea (Mimusops laurifolia) Pistachio (Pistacia spp) } \\
\text { Mistletoe (Plicosepalus curviflorus) Tamarind (Tamarindus indica) White clover } \\
\text { (Trifolium repens) Star fenugreek (Trigonella stellata) } \\
\text { Christ's thorn jujube (Ziziphus spina-christi) }\end{array}$ \\
\hline $\begin{array}{l}\text { Production of oxygen, gas } \\
\text { regulation }\end{array}$ & $\begin{array}{l}\text { Acacia(Acacia spp) } \\
\text { Mangrove grass (Aeluropus lagopoides) Garlic (Alliums pp) } \\
\text { Mediterranean saltbush (Atriplex halimus) Grey mangrove (Avicennia marina) } \\
\text { Neem tree (Azadirachta indica) Cabbage (Brassica oleraceae) Carob tree (Ceratonia } \\
\text { siliqua) Ceratonia (spp) Chickpea (Cicer arietinum) Cicer spp } \\
\text { Pumpkin (Cucurbita pepo) Alqa (Dipterygium glaucum) White saxaul (Haloxylon } \\
\text { persium) Sunflower (Helianthus annuus) }\end{array}$ \\
\hline
\end{tabular}




\begin{tabular}{|c|c|}
\hline & $\begin{array}{l}\text { Barley(Hordeum spontaneum, H. vulgare) Common juniper (Juniperus communis) } \\
\text { Lentil (Lens culinaris) Tomato (Lycopersicon esculentum) Alfalfa (Medicago sativa) } \\
\text { Persea (Mimusops laurifolia) }\end{array}$ \\
\hline & $\begin{array}{l}\text { Moringa (Moringa spp) Odyssea mucronata Cactus (Opuntia spp) } \\
\text { Desert bunchgrass (Panicum turgidum) Datepalm (Phoenix dactylifera) Common } \\
\text { reed (Phragmites australis) Pistachio (Pistacia spp) } \\
\text { Pea (Pisum sativum) Mistletoe (Plicosepalus curviflorus) Bulbous bluegrass (Poa } \\
\text { bulbosa) Poplar (Populus spp) } \\
\text { Bridal broom (Retama monosperma) Mesquite (Prosopis juliflora) Saltwort (Salsola } \\
\text { spp) } \\
\text { Silverleaf nightshade (Solanum eleagnifolium) Johnsongrass (Sorghum halepense) } \\
\text { Marigold (Tagetes eracta) Tamarind (Tamarindus indica) } \\
\text { Arabian tamarisk (Tamarix Arabica) White clover (Trifolium repens) } \\
\text { Star fenugreek (Trigonella stellata) Ervil (Vicia ervilia) } \\
\text { Vetch (Vicia sativa) } \\
\text { Christ's thorn jujube (Ziziphus spina-christi) }\end{array}$ \\
\hline Not specified & $\begin{array}{l}\text { Blackthorn (Acacia mellifera) } \\
\text { White stern thorn (Acacia polycantha) Red acacia (Acacia seyal) } \\
\text { Paper back thorn (Acacia sieberiana) Baobab (Adansonia digitata) } \\
\text { Silk tree (Albizia aylmeri) } \\
\text { Grey mangrove (Avicennia marina) African fan palm (Borassus aethiopum) } \\
\text { Large-leaved saucer-berry (Cordia africana) }\end{array}$ \\
\hline & $\begin{array}{l}\text { African ebony (Diospyrosmespiliformis), Winter thorn (Faidherbia albida), Phalsa } \\
\text { cherry (Grewia tenax) } \\
\text { Sea cucumber (Holothuria scabra), Doum palm (Hyphaene thebiaca)African } \\
\text { mahogany (Khaya senegalensis) } \\
\text { African bamboo (Oxytenanthera abyssinica), Dryzone cedar (Psedocedrela kotschyi) } \\
\text { Small-leaved blood wood (Pterocarpus lucens), Tamarind (Tamarindus indica) }\end{array}$ \\
\hline
\end{tabular}

\section{Benefits of Ecosystem Services}

The estimated monetary values of some regulatory ecosystem services for tropical ecosystems are shown in (Table 3). The value of just four services estimated for Nigeria 92,378,800 hectares stood at over N98 trillion/year (at $\$ 1=\mathrm{N} 200$ ).

Table 3 Estimated monetary values of Ecosystem Services

\begin{tabular}{|l|l|l|l|}
\hline Ecosystem Service(a) & \$/ha/year(b) & N/ha/year(c) & N/ha/year(d) $* *$ \\
\hline Regulation of climate & 1,965 & 393,000 & $36,304,082,400,000$ \\
\hline Water circulation flow & 1,360 & 272,000 & $25,126,489,600,000$ \\
\hline Soil stabilization & 694 & 138,800 & $12,821,899,840,000$ \\
\hline +NTFP+Wood+ & & & \\
\hline Medicine & 1,313 & 262,600 & $24,258,147,680,000$ \\
\hline Total & 5,332 & $1,066,400$ & $98,510,619,520,000$ \\
\hline
\end{tabular}

The Role of ecosystem services in the attainment of Sustainable Development Goals is of high significance. These goals include eradication of poverty and hunger, promotion of gender equality and empowerment of women, reduction of 
child mortality and improvement of maternal health, reduction of the spread of diseases and sustenance of natural environmental functions [34]. Government development strategies usually focus more on infrastructural growth while functionality of natural systems are deemed free hence unnoticed. This seems to be partly due to the fact that ecosystem services are often invisible and intangible coupled with a poor understanding of the cause-and-effect nature of environmental changes [35]. Similarly, long-term impacts of destroying ecosystems are sometimes difficult to anticipate or even substantiate, and biodiversity loss and degradation of ecosystems may not have immediate drastic impacts [36].

\subsection{Watersheds, Wetlands and Ecosystem Services in North East Nigeria}

Four of the of the seventeen primary watersheds in Africa are located in the Western part of the sub-continent namely the Senegal River Basin, the Volta River basin, the Niger River Basin and the Lake Chad Basin [37]. The Lake Chad basin spreads to over seven countries, two of which are in West Africa, Nigeria, (Northeast), Niger, Algeria, Sudan, Central Africa Republic, Chad and Cameroon [38]. The estimated value of ecosystem services that can be attributed to inland watershed and wetlands ranges between US $\$ 5000$ and US $\$ 100,000$ per hectare, while coastal watersheds and wetlands were between US $\$ 500$ and USD $\$ 1,000,000$ per hectare in 2007 [39]. The economic value of Hadejia-Nguru wetlands which forms part of the Komadougou - Yobe River Basin of the Lake Chad Basin in North East Nigeria was estimated at over US\$16million per year [40].

Hadejia - Nguru wetlands supports at least 250 species of flowering plants, over 136 types of aquatic flora and fauna, more than 103 fish species and 378 species of birds [41]. Several forests within the wetlands provide a range of natural resources. Fisheries and aquaculture activities account for 50\% in the wetlands representing the main source and livelihoods of the indigenous communities and is carried out throughout the year [42]. Blench, 2013 [43], reported that some 19 species are regularly caught in the wetland. The Hadejia - Nguru wetlands contribute to about $6 \%$ of inland fish catch in Nigeria with a market value of nearly US\$6million per annum [44].

\subsubsection{Agriculture, Wildlife and Fisheries in North-East Nigeria}

Agriculture is common to the six states of the North-East Region. Similar crops such as maize, sorghum, millet, groundnuts, and soya beans are cultivated. Livestock rearing and grazing are also practiced.

\section{Adamawa state}

This state is a picturesque environment with alluring mountain ranges on its eastern borders with Cameroon heavily dissected upland plains in the Southern parts and the Benue trough bisecting the state into two equal parts. Abundant agricultural lands are to be found in the many morphological units within the state making the growth of various crops, vegetables and livestock management possible. Several swamps/wetlands, lakes and pools exist to varying degrees. The landscapes support Guinea and Sudan savanna vegetation types though altered in many places due to anthropogenic forces.

\section{Taraba state}

This state shares a number of biophysical characteristics with Adamawa state. It is traversed by the Benue River with many tributaries but being more southerly enjoys higher and longer duration of rainfalls with vegetation of better verdure even though under serious threat from increased agricultural activities and fuel wood harvests. The state also possesses the Mambilla plateau (at more than 1800 metres above sea level), the largest national park (the GashakaGumti-6731 km $\mathrm{km}^{2}$ and extensive flood plains and marsh land. It has the highest variety of wildlife and flora given its moist forest, guinea savanna and mountain grasslands. In addition to its wide range agricultural potentials, Taraba state possesses high hydro-energy promise [45].

\section{Bauchi state}

This state is next to Borno in landmass and the highest in population within the region. Its wide expanse of plains and open savanna punctuated by isolated ruwares and inselbergs, rivers and flood plains (fadama) have long been supporting cultivation and livestock. The Yankari Game Reserve $\left(2,058 \mathrm{M}_{2}\right)$ which was opened to the public in 1962 is regarded as Nigeria's premier wildlife reserve [46].

\section{Gombe state}

This state is the smallest in land mass and the highest in density. Gombe plains have long supported grains, vegetables and cotton production in places with morphological and scenic beauty such as Kalan, Bima rocks, Tangale peak and Bage hills, Cham valley and surrounding hills have all been supporting advanced forms of cultivation and management 
including terracing. Dadin Kowa dam is supporting irrigated agriculture on the banks of the Gongola River and in other nearby lowland plains [47].

\section{Borno state}

This is the largest state in the North-East Region of Nigeria and the second largest in Nigeria with a vast open strikingly uniform plain of sedimentary formation, largely within the Mega Chad Basin [48]. Rivers Yedsram and Alau flowing from south to north now disappear into firkin (dark clayey soils that easily get saturated during rainy season) swamps. The southeastern Mandara mountains and the Biu plateau in the south contrast sharply with the sand dunes of the North and North-West of the state. Lake Chad being one of the largest and most historic endorheic lakes in the world is perhaps the most significant hydro-ecological feature of the North-Eastern tip of Nigeria necessitating the establishment of the Lake Chad Basin Commission by the four countries(Chad, Cameroon, Niger, Nigeria) adjoining it [49]. The lake's fisheries(with 176 species) are said to be of international importance [50] and together with the huge spread of irrigable lands and also the Chad Basin National Park $\left(2,258 \mathrm{~km}^{2}\right)$ supporting various birds and lowland/marshy area wildlife, the basin is of economic importance in the region [51].

Yobe state

This state has a very large landmass and a very low population. It has the lowest density of only 31 persons $/ \mathrm{km}^{2}$.It is a state dominated by gently low-lying plains of loose friable soils except in the fadamas/depressions that get saturated during rains and the major water courses and wetlands [52]. The wetlands are of international importance supporting cultivation, grazing, fishing and hunting. The Bade-Nguru sector of the Chad Basin National Park(938km2) is also within the state [53].

\section{Dynamics of fuel wood consumption in North-East Nigeria}

Most forest reserves in North East Nigeria are depleted of trees and Non-Tree Forest Products (NFTP) which is exacerbated by the level of poverty in this region. A correlation coefficient of 0.771 (significant at $5 \%$ ) shows that the poorer regions tend to use more wood fuel to meet their domestic requirements [54]. Table 4 shows the average percentage of wood used in 2007 in each of the six geopolitical regions of Nigeria in relation to poverty level. Northern regions of Nigeria (North East inclusive) consume more fuel wood than Southern regions of Nigeria [55].

Table 4 Poverty rate and percentage of wood as fuel source by geopolitical regions

\begin{tabular}{|l|l|l|}
\hline Region & Poverty rate (\%) & Wood as fuelwood source (\%) \\
\hline North-East & 72.2 & 95.9 \\
\hline North-West & 71.2 & 95.3 \\
\hline North-Central & 67.2 & 86.4 \\
\hline South-West & 43.0 & 54.9 \\
\hline South-East & 26.7 & 78.0 \\
\hline South-South & 35.1 & 72.7 \\
\hline
\end{tabular}

Table 5, shows removals of wood from the forests according to purposes in Nigeria. Wood removals from forests in 2005 amounted to 86,626,797 $\mathrm{m}_{2}$ and removals for wood fuel from forests in the year 2005 were $72,710,935 \mathrm{~m}_{2}$, the difference being made up by industrial round wood which accounted for 13,915,862 [56]. Wood may also come from areas outside forests like shrub land, savanna and grassland as no data are available on these sources in Nigeria, a reasonable estimate has to be made based on figures from neighboring countries. Neither are data available for Benin, Cameroon or Ghana. The "FRA 2005 Country Report Senegal" presents data on the growing stock on "other wooded land" is about 7\% of the growing stock of forests. This can be assumed to be true for Nigeria. Adding 7\% to 86,626,797m2 gives us $92,690,673 \mathrm{~m}_{2}$ as the total harvest of wood from forest and other wooded land combined. 
Table 5 Removals according to purposes in Nigeria.

\begin{tabular}{|l|l|l|}
\hline Category & $\mathbf{M}^{3} /$ year & Tonnes/year (Metric) \\
\hline Total removals & $92,690,673$ & $64,883,471$ \\
\hline Of which for fuel & $72,711,000$ & $50,897,700$ \\
\hline Of which for fuel wood proper & $56,714,580$ & $39,700,206$ \\
\hline & & \\
\hline \multicolumn{2}{|l}{ Source: FAO (2005) } \\
\hline
\end{tabular}

The shares of fuel wood proper and wood for charcoal production are not known. We can assume it to be about the same as in Chad which is 78 and $22 \%$ respectively of all the wood used [57].

UNDP, 2002 [58], gives the share of various energy sources in the total primary energy supply in Nigeria as $10.4 \%$ oil, $6 \%$ gas, $0.6 \%$ hydro and commercial renewable energy $83 \%$.The greater portion of the commercial renewable energy is wood while other agricultural wastes constitute the remaining smaller portion, lower prices, easy accessibility, constraints in the supply of the conventional fuels and growing population are reasons for over-dependence on fuel wood for energy [59]. Daily consumption of firewood by the rural communities in Nigeria is estimated at 27.5 million $\mathrm{kg} /$ day [60], and estimated Nigeria's fuelwood consumption in relation to other energy sources at 87\%. This implies that majority of the Nigerian rural people will continue to use dried biomass fuels for energy many years to come [61].

\subsection{National wood fuel consumption}

Dividing the total fuel wood consumption of 39,700,206 tonnes/year through the number of inhabitants which is $140,003,542$ (2006 census) we get about 0.284 tonnes/person/year which is about $0.776 \mathrm{~kg} /$ day [62]. The difference between urban and rural households may be explained by the fact that urban households often have additional sources of energy at their disposal e.g., kerosene, gas, charcoal, agricultural residues, electricity.

\subsection{Data on some savanna wood species and domestic sources of energy}

Average calorific value of savanna wood species is about 4,167 k.cal [63].

Calorific values of kerosene, liquefied petroleum gas, charcoal and electricity are 8, 300, 11,700,600 and 860 k.cal. With fuel use efficiency of 35\%, 52.5\%, 20\% and 75\% respectively [64].

With the traditional wood burning stoves in use, fuel end-use efficiency of firewood is about 7.5\% [65].

Mechanical equivalent of heat- 4.2 joules per calorie

1M3 solid volume of savanna tree species at about 13\% moisture content (dry wood weighs about 600kg [66].

For the purpose of estimation, 100-kg sack of charcoal weighs $335 \mathrm{~kg}$ [67].

1M3 stacked wood volume=1/2 M3 solid wood volume

Among other sources of domestic energy, firewood was the most highly consumed accounting for about $82 \%$ of the estimated total heat of energy of 104 mega joules consumed per person per year in Kaduna state [68]. (Adegbehin and

\subsection{Fuelwood consumption in North East Nigeria}

State-specific consumption figures are not available, but multiplying the national average of 0.284 tonnes/person/year [69] with the number of inhabitants in the North-East which is 24,051,418(2006 census projected to mid-2014 [70], we arrive at an estimated consumption of 6,830,603 tonnes/person/year in the six North-Eastern states of Adamawa, Gombe, Taraba, Yobe, Bauchi and Borno put together. As a result of population growth these consumption figures should be higher now. 


\section{Threats to ecosystem services in North East Nigeria}

\subsection{Over exploitation of forest resources}

West Africa original forest has disappeared with small fragments of these natural forests existing in Cote d'Ivoire, Nigeria (including the North East) and Cameroon [71]. Over exploitation of forest resources is a serious factor causing biodiversity losses in Northeast Nigeria, and this scenario is exacerbated by poverty, ignorance and lack of awareness and education about the importance and value of the forest. According to Olagunju, 2015 [72], Nigeria is considered the world's highest deforested country and has lost about 55.7\% of its primary forest. From 1990 to 2010, Nigeria nearly halved the amount of it primary forest cover with an annual deforestation rate of 3.67\% between 2000 and 2010 [73].

\subsection{Drought, desertification and ecosystem services}

Drought and desertification have direct impact on the availability of ecosystem services in Northeast Nigeria. Some of the causes of these phenomena include climatic variability [74], anthropogenic activities which include deforestation [75], extensive cultivation whereby conversion of 351,000 hectares of land are reduced to desert, overgrazing [76]; [77]. More than 70\% of the nation's population depends on fuel wood [78]. Katsina has its over $90 \%$ energy from fuel wood [79].

\subsection{Urbanization}

Urbanization, according to Nneji, 2013 [80] is also a factor for desertification; lands are cleared to make way for infrastructure leading to removal of vegetation cover thereby paving way for desertification.

Table 6 shows various degree of desertification in frontline states of Nigeria. Notably, seven states, Sokoto, Zamfara, Katsina, Jigawa, Kebbi, Borno and Yobe experience severe levels of desertification.

\begin{tabular}{|c|c|c|c|c|c|c|}
\hline \multirow[t]{2}{*}{ State } & \multirow{2}{*}{$\begin{array}{l}\text { Geographical } \\
\text { Region }\end{array}$} & \multicolumn{4}{|c|}{ Population (2006) } & \multirow{2}{*}{$\begin{array}{l}\text { Rate of } \\
\text { Desertification }\end{array}$} \\
\hline & & $\left(\mathrm{Km}^{2}\right)$ & $\begin{array}{l}\% \quad \text { of } \\
\text { Nigeria }\end{array}$ & Number & $\begin{array}{l}\text { Density } \\
\left(\mathrm{Km}^{2}\right)\end{array}$ & \\
\hline Sokoto & Northwest & 27,825 & 3.06 & $3,702,676$ & 133 & Severe \\
\hline Zamfara & Northwest & 37,931 & 4.17 & $3,278,873$ & 86 & Severe \\
\hline Katsina & Northwest & 23,561 & 2.59 & $5,801,584$ & 246 & Severe \\
\hline Jigawa & Northwest & 23,287 & 2.56 & $4.361,002$ & 187 & Severe \\
\hline Kano & North central & 20,280 & 2.23 & $9,401,286$ & 464 & Moderate \\
\hline Kebbi & Northwest & 36,985 & 4.06 & $3,256,541$ & 88 & Severe \\
\hline Kaduna & North central & 42,481 & 4.67 & $6,113,503$ & 144 & Moderate \\
\hline Borno & Northeast & 72,609 & 7.98 & $4,171,104$ & 57 & Severe \\
\hline Yobe & Northeast & 46,609 & 5.12 & $2,321,339$ & 50 & Severe \\
\hline Bauchi & Northeast & 41,119 & 4.52 & $4,653,066$ & 113 & Moderate \\
\hline Gombe & Northeast & 17,100 & 1.88 & $2,365,040$ & 138 & Moderate \\
\hline Adamawa & Northeast & 38,700 & 4.25 & $3,178,950$ & 82 & Moderate \\
\hline Taraba & Northeast & 56,282 & 6.19 & $2,294,800$ & 41 & Moderate \\
\hline Niger & North central & 68,925 & 7.58 & $3,954,772$ & 57 & Moderate \\
\hline Plateau & North central & 27,147 & 2.98 & $3,206,531$ & 118 & Moderate \\
\hline Total & & 580,841 & 63.83 & $62,061,067$ & 2004 & \\
\hline
\end{tabular}


Moderate: 26 to $50 \%$ of plant community consists of climax species or 25 to $75 \%$ of original top soil lost or soil salinity has reduced crop yields 10 to $50 \%$ severe: 10 to $25 \%$ of plant community consists of climax species or erosion has removed all or practically all of the top soil or salinity controlled by drainage and leaching had reduced crop yield by more than $50 \%$ Loss of Biodiversity and habitat destruction.

The impact of desertification is far reaching and results in habitat destruction and loss of biodiversity as many species are prone to be endangered due to desertification [81], changes in phenology, heat waves [82], [83],cancer [84],vectorborne diseases [85], loss of plants of medicinal importance [86], [87], global warming [88],increased erosion, soil salinization [89], [90], [91], reduced water supply, [92]; [93]; [94], [95], overexploitation of groundwater, reduced agricultural productivity and food insecurity [96], economic loss and reduced economic growth [97], [98], migration, resource use conflict [99], [100], [101], [102], [103], [104].

In West Africa, biodiversity hubs characterize the environmental landscape and are crucial to the livelihood of citizens. In Northern Nigeria forests, vegetation and wetlands are primary providers of ecosystem services.

These hubs are being threatened by agricultural expansion, overexploitation of biological resources, population exploitation of biological resources, population explosion, urbanization and climate change [105]. The utilization of industrial chemicals for agricultural purposes, as well as pesticide discharges are threatening the quality and volume of native flora and fauna species in watersheds and wetlands across sub-Saharan Africa [106]. The size of these hubs have been degraded and reduced in parts of West Africa, Northeast Nigeria inclusive [107].

It was reported that fish catches in the wetlands reduced by $17 \%$ due to flooding while invasive Typhadomingens is reduced fish catch and prevented fishermen from having access to other parts of the wetland [108].

\subsection{Anthropogenic activies, pollution and wetlands}

Akinsolaet.al., 2000 [109]; Abubakar and Abubakar, 2013[110], listed the following threats to the optimum functioning of the Hadejia-Nguruwetlands,as over exploitation of natural resources, uncontrolled hunting, population increase, pollution from domestic waste, potash exploration, sedimentation resulting from deforestation ,desertification, eutrophication resulting from agricultural run-off, channelization, compaction of soil by pastora list and their animals which further degrade the wetlands habitats as well as climate change and drought. Olofin, 1993 [111], pointed out that drying out effects of the wetlands and some Pale arctic waders thus paving way for infestation by entomodestesleucotis. Bird life international, 2015 [112] ranked the status of the wetlands in terms of pressure as "very high" in addition to outdated management plan which is not comprehensive.

\subsection{COVID19 pandemic and ecosystem services}

The current siege of COVID-19 globally is a threat to the entire configuration of demand and supply of eco system services in Northeast Nigeria. As at $1^{\text {st }}$ May, 2020, Nigeria has recorded over 2000 cases with over 40 deaths. All the states in Northeast Region Yobe, Adamawa, Borno, Gombe, Bauchi and Taraba have recorded cases of COVID-19, resulting in lockdowns, curfews, ban in interstate travel, culminating in suggested practices of social standing, reduction in people gathering for social activities, all having concomitant effects on provision of ecosystem services.

\section{Mitigating threats to ecosystem services sustainability}

\subsection{Assessing Demand and Supply of Ecosystem Services}

Millennium Ecosystem Assessment (MEA 2005) [113], established an understanding of ecosystem services and how human activities affect them [114] and concluded that $60 \%$ of ecosystem services were degraded or being used unsustainably. A framework for assessing when, where and how ecosystem services are imperiled in North East Nigeria is crucial. Which of the ecosystem services should we be most concerned about? Fuel wood supply, bush meat, charcoal, medicines from products of tree barks, wild fruits from trees, fishing, livestock and animal husbandry among many other ecosystem services. Hence it is important to establish standard set of criteria to find out when and to what extent provision of ecosystem service is at risk of extinction based on international Union for Conservation of Nature (IUCN) red list classification systems [115]; [116].

The proposed threat categorization framework for Ecosystem services. Description of the criteria for each of the seven proposed threat categories plus a data deficient category showing the critical thresholds where services transition from secure at risk, as risk to undersupplied and undersupplied to lost. Burkhard, 2012 [117] opined that level of risk to 
"adequate" ecosystem service provision whether supply meets demand must be evaluated. This is because the absolute level of service provision is not the appropriate metric for evaluating threat [118]. Any threat assessment framework must evaluate both ecosystem service supply (the potential for natural capital to generate benefit for people) [119], and demand (the level of service provision desired or acquired by people [120].

Ecosystem services in North East Nigeria can be categorized in order to establish functional thresholds so as to know which ecosystem services supply and demand are imperiled [121].

Table 7 Suggested frame work for Ecosystem threat analysis

\begin{tabular}{|c|c|c|}
\hline Category & Definition & Threshold \\
\hline $\begin{array}{l}\text { Functionally } \\
\text { extinct }\end{array}$ & Service no longer supplied in the region and is practically unrecoverable & \multirow[t]{2}{*}{ Lost } \\
\hline Dormant & Service no longer supplied in the region but is potentially recoverable & \\
\hline $\begin{array}{l}\text { Critically } \\
\text { endangered }\end{array}$ & $\begin{array}{l}\text { Current levels of demand exceed supply and the ratio of supply to demand declining } \\
\text { or expected to decline. }\end{array}$ & \multirow[t]{3}{*}{$\begin{array}{l}\text { Under } \\
\text { supplied }\end{array}$} \\
\hline Endangered & $\begin{array}{l}\text { Current levels of demand exceed supply; ratio of supply to demand is stable but supply } \\
\text { is declining }\end{array}$ & \\
\hline $\begin{array}{l}\text { Stable but } \\
\text { undersupplied }\end{array}$ & $\begin{array}{l}\text { Current levels of demand exceed supply; neither supply nor ratio of supply to demand } \\
\text { declining }\end{array}$ & \\
\hline Vulnerable & $\begin{array}{l}\text { Ratio of supply to demand is declining or expected to decline such that supply is likely } \\
\text { to be insufficient to meet demand within a set time horizon }\end{array}$ & At risk \\
\hline Least Concern & Supply currently meets or exceeds demand and does not the criteria for vulnerable & Secure \\
\hline Data deficient & $\begin{array}{l}\text { Inadequate information is available about either or both of supply and demand to } \\
\text { assess the level of threat }\end{array}$ & $\mathrm{N} / \mathrm{A}$ \\
\hline
\end{tabular}

Source: Maron et al, 2017; Trends in Ecology and Evolution

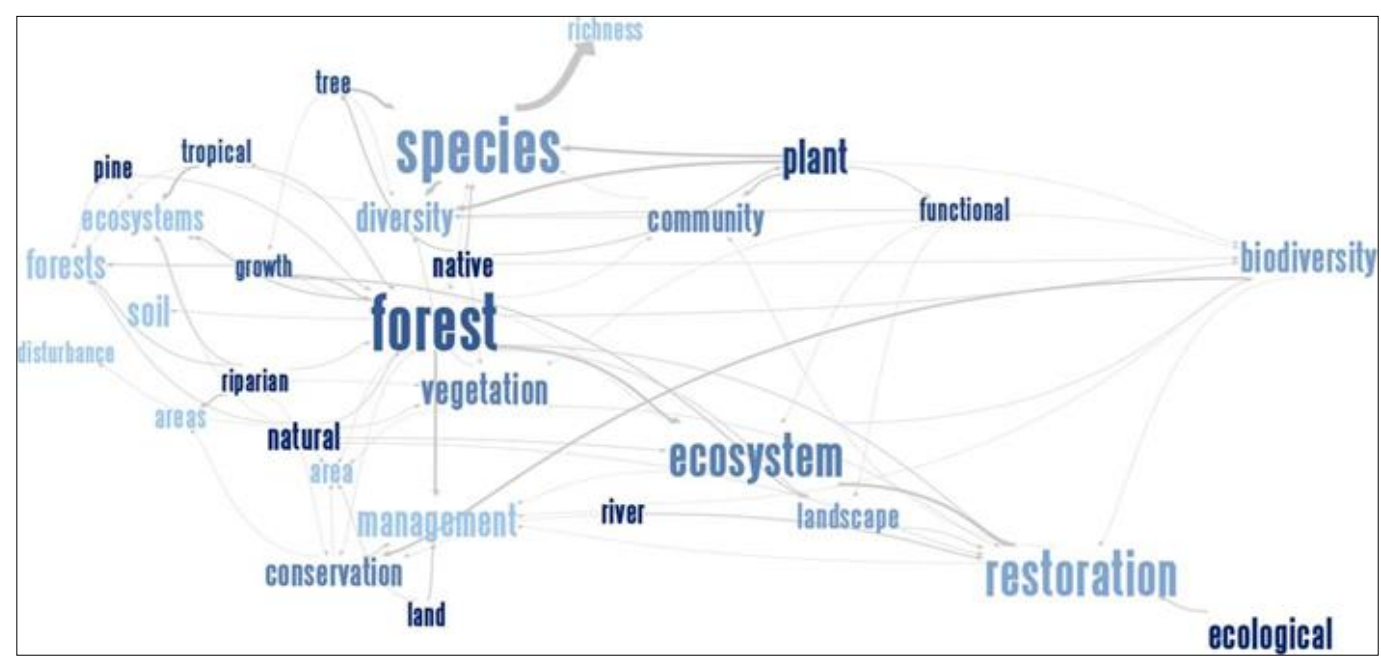

Figure 2 Shows the biodiversity-ecosystem function approach to ecological forest restoration

\subsection{Applying ecosystem approach}

The need to restore ecosystem functions in North East Nigeria cannot be overemphasized. Most of the forest reserves are deforested and have become degraded, hence reforestation of their sites with trees are necessary adopting the example of the ecosystem approach to forest restoration suggested by (Russel, et al., 2004) [122]; Paul et al., 2010) [123]. 
Some authors Naeem, 2006 [124], Wright et al, 2009 [125], Tree Div Network suggested the biodiversity-ecosystem function (BEF) approach to ecological forest restoration as illustrated in (fig 2). The BEF perspective strongly focuses on restoring the relationship between biodiversity and ecosystem functioning [126]. These suggestions are valuable in restoring ecosystems in North-East Nigeria for the purpose of sustaining ecosystem services.

\subsection{Mitigating wood shortage problems}

Strategies for combating wood shortage in the North-East Nigeria could include the short- and long-term measures. Firewood is a very relevant commodity in provision of ecosystem services in this region and even in the Nigerian nation; therefore, every effort to ameliorate shortage of this commodity is worthwhile.

\subsubsection{Short-term measures}

In the short term, improved stoves and pressure pot cookers should be provided and distributed to the inhabitants of this region i.e., North-East Nigeria. The traditional African 3-stone hearth loses over 90\% of the heat produced [127]. These stoves which can be fabricated locally reduce heat loss and save about $27.5 \%$ of firewood input and at the same time reduce the cooking time by about $42.6 \%$ [128]. Government should continue to subsidize the prices of non-fuel wood sources, principally gas and kerosene to reduce consumption of fuel wood.

\subsubsection{Long-term measures}

Intensified afforestation

According to Repetto, 1988 [129], the rate of deforestation in Nigeria has been estimated at about 300,000 hectares annually while afforestation rate is less than $10 \%$ of the rate of deforestation [130]. This calls for increased rate of afforestation. Promising plantation species such as Eucalyptus camaldulensis, Eucalyptus tereticornis, Gmelina arborea, Tectona grandis which have growth rate over ten times that of most indigenous tree species [131], should be planted as fuel wood plantations by individuals and intensified agro forestry practices by farmers should be encouraged as part of finding solution to fuel wood problems in this region.

\section{Use of Solar energy}

The use of solar energy to generate electricity for lighting, cooking and many other household chores is still at a smallscale use in Nigeria including the North-East [132]. Sun energy is man's oldest and most important source of energy and there is abundance of sunshine in North- East Nigeria. For Nigeria, there is an average yearly incidence of solar energy at about 2,300 Kwh/m² of land area. With a projected yearly total demand of about 21 multiplied by 109 Kwh for the remaining part of this century, the entire energy requirement of the whole country could in principle be met by solar if $1 \%$ of the available solar energy can be tapped at $0.1 \%$ conversion efficiency [133].

\section{Other sources of energy}

Other sources of energy that can be developed in North-East Nigeria include windmill which can be used to grind grain harvests from the farms and support other activities in the entire ecosystem services value chain.

Biogas technique can also be used for the production of heat energy which can be derived from gas produced from decaying animal wastes/or plant materials.

The use of human wastes which are abundant in good quantity for this purpose needs to be encouraged although there may be problem of acceptance by the public. System services provisions.

\section{The Role of forest extension in sustaining Ecosystem Services in North East Nigeria}

\subsection{Co-ordination of research and extension}

Forestry extension is vital in the sustainability of ecosystem services in Northeast Nigeria. Improved research and training are necessary to support the process towards sustainability of ecosystem services. Agbogidi and Ofuoku (2005) [134] opined that integrated data analysis on forest management and extension should be properly co-ordinated and synergized in the country including North-East. 


\subsection{Capacity building for indigenous people and institutions}

In order to ensure that ecosystem services are sustained in North East Nigeria, there is need to build capacity at all the local governments in the entire region in line with designed extension packages. Institutional and human capacity should be built among indigenous peoples of the region. These extension ingredients are crucial to sustainable ecosystem services and also suggested for North East Nigeria. There is need to invest in environmental protection technologies, public education and poverty reduction.

\subsection{Investing in forestry protection technologies}

- Proper funding of forestry extension packages recognizing extension as a priority.

- Women who are major end users of forest products must be adequately reached by extension services in any of the forest protection development programmes.

- The missing linkages between research and extension organization need to be retraced and strengthened.

- Researchers should not be skewed away from sustainable systems of local subsistence way of life of the local communities, there is need to interface with members of the community in forestry programme planning and implementation.

- Forest valuation should be carried out and mechanisms that will support conservation of forest ecosystems and sustainable forest- based development given a top priority.

- Opinion, religious and community leaders are revered by their subjects in this part of the country and can be encouraged to pass on the message of the value and importance of biodiversity conservation to their subjects.

\section{Conclusion}

Ecosystem services sustainability is vital to the North East Region of Nigeria due to the many benefits accruing to the inhabitants. Sustainable development goals, such as eradication of poverty and hunger, promotion of gender equality, sustenance of the natural environment, watersheds and wetlands are beneficial to ecosystem services. Threats to ecosystem services supply and demand in this region include (but not limited to) drought, desertification, overexploitation of natural resources, urbanization, progressive industrialization and overgrazing. In order to mitigate these threats, there is need to develop a framework for assessing when, where and how demand and supply of ecosystem services are imperiled. Secondly, restoration of ecosystems is crucial because most forests and forest reserves are badly depleted through over exploitation of trees and non-forest tree products (NFTPs). Thirdly, forestry extension services must be geared up to create awareness on the value and importance of trees and the deleterious effects of their removals and consequent threats to the ecosystems.

\section{Compliance with ethical standards}

\section{Acknowledgments}

The author appreciates various authors and agencies who permitted the consultation of different categories of publications in the course of preparing this review paper.

\section{References}

[1] Constanza, R, Arge R, dGrootR, Farber S, Grasso, M, Hannon, B. Limburg, K. Naeem, S. Oneill, RV. Paruelo, IM Raskin, RG, Sutton, P. VandenBelt, M. (1997). The value of the world's ecosystem services and natural capital Nature 387(6630):1997:253-260.

[2] Ricketts, TH, Daily, GC, Ehrlich, PR, Michener, CD. Economic value of tropical forests to coffee production. Proceedings of National Academy of Sciences, USA 2004:101(34):12579-12582.

[3] Kremen, C. Managing ecosystem services:What do we need to know about their ecology?Ecology letters. 2005:8:468-479.

[4] Dasin, MS\& Tukur, AL, Population, poverty and Resources utilisation amongst ethnic groups in Fufore Area of Adamawa State, Nigeria. International journal of Environment, Ecology, Family and Urban Studies Vol. 3, issue Pp1-10.

[5] TEEB(2010) The economics of Ecosystems and Biodiversity for Local and Regional policy makers. UNEP. 210p. 
[6] Arowolo, AO, Xiangzheng, D, Abiodun, O, Obayelu, E. Assessing changes in the value of ecosystem services in response to land use/land cover dynamics in Nigeria. Science of the total environment. Vol. 36:Elsevier. Pp59769.

[7] Arowolo, AO, Xiangzheng, D, Abiodun, O, Obayelu, E. (2018) Assessing changes in the value of ecosystem services in response to land use/land cover dynamics in Nigeria. Science of the total environment. Vol. 36:Elsevier. Pp59769.

[8] Arowolo, AO, Xiangzheng, D, Abiodun, O, Obayelu, E. (2018) Assessing changes in the value of ecosystem services in response to land use/land cover dynamics in Nigeria. Science of the total environment. Vol. 36:Elsevier. Pp. 597-69.

[9] Arowolo, AO, Xiangzheng, D, Abiodun, O, Obayelu, E. (2018) Assessing changes in the value of ecosystem services in response to land use/land cover dynamics in Nigeria. Science of the total environment. Vol. 36:Elsevier:Pp. 597-69.

[10] Maron MM, GE, Mitchell, Runting, RK, Rhodes, JR, Mace, GM, Keith, DA \&Watson, JEM (2017) Towards a threat assessment framework for ecosystem services. Trends in Ecology \& Evolution. http//dx. doi. org/10. 1016/tree 2016. 12. 011. 2017. ElsevierLtd.

[11] Tukur, AL (2015) Tragedy beyond the commons: livelihood and environmental challenges in North- Eastern Nigeria. $21^{\text {st }}$ inaugural lecture held at Modibbo AdamaUniversity of Technology, Yola. Nigeria. December, $2^{\text {nd }}$.

[12] Tukur, AL (2015) Tragedy beyond the commons:livehood and environmental challenges in North-Eastern Nigeria. 21 stinuagural lecture held at Modibbo Adama University of Technology, Yola. Nigeria. December, 2 nd.

[13] Olagunju, TE(2015) Drought, Desertification and the Nigerian environment. Vol. 7 (7):Pp 196-209.

[14] Inkom, JN, S. Frank\&C Furst (2017) Challenges and opportunities of ecosystem services :intergration into land use planning in West Africa-an implementation framework.

[15] Gouwakinnou, CN, Biaou, S, Vodouhe, FG, Tovihessi, MS, Beranger, KA, Biaou. HSS. (2019). Local perceptions and factors determining ecosystem services in Northern Benin. Journal of ethnobiology and ethnomedicine. 15:61.

[16] Girardin, MP, Raulier, F, Bernier, PY, Tardif, JC. Response of tree growth to a changing climate in boreal central Canada: A comparison of empirical process-based and hybrid modelling approaches. Ecological modelling. 2018: 213 (2):209-228.

[17] Le Bauer, Ds \&Treseder, KK. Nitrogen limitation of net primary productivity in terrestrial ecosystems. Ecology $2008: 89$ (2) :371-379.

[18] McMillam, AM, Winston, GC \&Goulden, ML (2008) Age-dependent response of boreal forest to temperate and rainfall variability. Global change Biology 2008: 14(8):1904-1916.

[19] Ollinger SC, Goodle, Hayhoe, K. \&Jenkins, JP (2008) Potential effects of climate change and rising CO2 on ecosystem processes in North Eastern United States Forests. Mitigation and Adaption Strategies for Global Change. 13(5): 467-485.

[20] Phillips, OL, Lewis, SL, Baker, TR, Chao, K-J \& Higuichi, N. (2008)The changing Amazon forest. Philosophical Transactions of the Royal Society B: Biological Sciences $2008: 363$ (1498):1819-1827.

[21] Reich, PB \& Oleksyn, J. (2008) Climate warming will reduce growth and survival of Scots pine except in the far North. Ecological letters 2008:11 (6):588-597.

[22] Saigusa, N, Yamamot, S, Hirata, R, Ohtani, Y, Ide, R, Asanuma, J, Gamo, M, Hirano , T, Kondo, H, Kosugi, Y, Li, S-G, Nakai, Y. Takagi, K. T, Ani, M. \&Wang, H (2008) Temporal and spatial variations in the season pattern of CO2 flux in boreal, temperate and tropical forests in East Asia. Agricultural and Meteorology 2008: 148 (5): 700-713.

[23] Clark, DA, Piper, SC, Keeling, CD \&Clark, DB (2003) Tropical rainforest tree growth and atmospheric carbon dynamics linked to inter annual temperature variation during 1984-2000. PNAS 100 (10):5852-5857.

[24] Nepstad, DC, Stickler, CM, Soares-Filho \&Merry, F (2008) Interactions among land use forests and climate: prospects for a near-term forest tipping point. Philosophical transactions of the Royal Society B. Biological Sciences 2008: 363 (1498:1737-1746.

[25] Ollinger, SC, Goodale, Hayhoe, K. \&Jenkins, JP. (2008) Potential effects of climate change and rising CO2 on ecosystem processes in North-Eastern United States Forests. Mitigation and Adaptation Strategies for Global Change. 13 (5): 467-485. 
[26] Saigusa, N, Yamamoto, S, Hirata, R, Ohtani, Y, Ide, R, Asanuma, J, Gamo, M, Hirano, T, Kondo, H, Kosugi, Y, Li-S, G. Nakai, Y. Takagi, K. Tani, M, \&Wang, H. Temporal and spatial variations in the season patterns of CO2 flux in boreal , temperate and tropical forests in East Asia. Agricultural \& Forest Meteorology2008:148(5):700-713.

[27] Clark, DA, Piper, SC, Keeling, CD, Clark, DB 2003, Tropical rainforest tree growth and atmospheric carbon dynamics linked to interannual temperature variation during 1984-2000. PNAS 100 (10):5852-5857.

[28] Postel, SL\& Thompson, BH, Watershed protection:capturing the benefits on nature's water supply needs. Natural Resources Forum 2005: 29(2):98-108.

[29] Osman-Elasha, B. Parrotta, J, Adgar, N, Brockhaus, M, Pierce Colfer, CJ, Sohngen, B, Dafalla, T. Joyce, LA, Nkem, J, \&Robledo, C. 2009 Future socio-economic impacts and vulnerabilities In: Seppala, R, BJouck, A. \&Katila, P. (eds) 2009 Adaptation of forests and people to climate change. IUFRO World Series 22.

[30] Osman-Elasha, B. Parrott, J, Adgaa, N, Brockhaus, M, Pierce Colfer, CJ, Sohngen, B, Dafalla, T, Joyce, LA, Nkem, J, \& Robledo, C. 2009 Future socio-economic impacts and vulnerabilities. in: Seppala, R. Bjouck, A. \&Katila, P(eds) 2009 Adaptation of forests and people to climate change. IUFRO World Series 22.

[31] Osman-Elasha, B. Parrotta, J, Adgar, N, Brockhaus, M, PierceColfer, CJ, Sohngen, B, Dafalla, T. Joyce, LA, Nkem, J, \& Robledo, C. 2009 Future socio-economic impacts and vulnerabilities,. In: Seppala, R. Bjouck, A. \& Katila, P (eds)2009 Adaptation of forests and people to climate change. IUFRO World Series 22.

[32] Osman-Elasha, B. Parrotta, J, Adgar, N, Brockhaus, M, PierceColfer, CJ, Sohngen, B, Dafalla, T, Joyce, LA, \& Robledo. 2009 Future socio-economic impacts and vulnerabilities. In:Seppala, R. Bjouck, A. \&Katila, P. (eds) 2009 Adaptation of forests and people to climate change. IUFRO World Series22.

[33] Osman-Elasha, B. Parrotta, J, Adgar, N, Brockhaus, M, Pierce Colfer, CJ, Sohngen, B, Dafalla, T. Joyce, LA, Nkem, J, \& Robledo. 2009 Future socio-economic impacts and vulnerabilities. In:Seppala, R. Bjouck, A. \&Katila, P. (eds)2009 Adaptation of forests and people to climate change. IUFRO World Series22.

[34] Tella, IO, Our land, our home, our future: Ecosystem -Human partnership for Ecological and Climatic dividends. A paper presented on World Desertification Day at Gombe State, Nigeria. 2017.

[35] Tella, IO. Our land, our home, our future:Ecosystem-Human partnership for Ecological and Climatic dividends:A paper presented on World Desertification Day at Gombe State, Nigeria. 2017.

[36] Tella, IO. Our land, our home, our future: Ecosystem-Human partnership for Ecological and Climatic dividends: A paper presented on World Desertification Day at Gombe State, Nigeria. 2017.

[37] UMIC, Africa Primary Watersheds. University of Michigan, Ann arbor, MI, USA. Accessed 2 December, 2017.

[38] UMIC, Africa Primary Watershed. University of Michigan, Ann arbor, MI, US. Accessed 2 December, 2017.

[39] TEEB, 2013 The economics of Ecosystems and Biodiversity for watersheds and wetlands. Accessed, 6 May, 2017.

[40] TEEB, 2010 The economics of Ecosystems and Biodiversity for local and regional policy makers. UNEP 2010: $210 \mathrm{P}$.

[41] Oduntan, OO, Akinyemi, AF, Adetoro, AO\&Usunsina, IO, Seasonal variability of farmlands and its contribution in wildbirds land use conflicts in Hadejia-Nguru wetlands, Nigeria. African journal of Agriculture. 2010 : 63:131-137.

[42] Birdlife International 2015 Important Birdlife Areas Factsheets:Hadejia-Nguru wetlands Cambridge, United Kingdom.

[43] Blench, R, An overview of the context of the jewel project:Access rights and conflict over common pool resources on Hadejia-Nguru wetlands. A report prepared for the JEWEL project in the Hadejia-Nguru wetlands report of ITAD, Cambridge CB 12 AL, United Kingdom. 2013.

[44] Eaton, D. and Sarah, TM The economic importance of wildlife resources in the Economics of Environment and Development(CREED)-London (International Institute for Environment and Development)(NO. 13) working paper 1997:Pp10-19.

[45] Tukur, AL 2015 Tradegy of the commons: livelihood and environmental changes in North-Eastern Nigeria. 21 inaugural lecture held Modibbo Adama University of Technology, Yola. December, 2 nd.

[46] Tukur, AL, 2015 Tradegy of the commons: livehood and environmental changes in North-Eastern Nigeria. 21 inaugural lecture held at Modibbo Adama University of Technology, Yola. December, $2^{\text {nd. }}$. 
[47] Dasin, MS andTukur, AL. Population, poverty and resources utilization amongst ethnic groups in Fufore Area of Adamawa State. International journal of Environment, Ecology, family and urban studies 2013:Vol. 3, issue1:Pp. $1-10$.

[48] Tukur, AL, \&Barde, MM The geography of politics: A case for the political re-districting of Adamawa state, Nigeria. Journal of Humanities and social sciences 2014a: Vol. 19 issue 1 Pp12-22.

[49] Tukur, AL. 2015Tradegy of the commons:livelihood and environmental changes in North-Eastern Nigeria. 21 st inaugural lecture held at Modibbo Adama University of Technology, Yola. December2nd.

[50] Ladu, BMB, Environmental change and sustainability of fish resources in the lake Chad Basin. 19th inaugural lecture held at Modibbo Adama University of Technology, Yola, Nigeria. 2015.

[51] Abubakar, MM \&Abubakar, JY(2013)Some aspects of the Limnology of Ngure lake, North West Nigeria. International journal of Basic and Applied Sciences. 2:2:140-144.

[52] Olofin EA, Dam- induced drying-out of the Hadejia-Nguru wetlands, Northern Nigeria and its implications for the fauna:In Proceeding, African Crane and Wetland training workshop. 1993.

[53] Olalekan, EI, Abimbola, LM, Saheed, M, Damilola, OA, Wetland resources of Nigeria:case study of the HadejiaNguru wetland. Poultry, Fisheries and Wildife Sciences 2014: 2:123, 2-6.

[54] Zaku, SG, Kabir, A, Tukur, AA, Jimento, IG, Wood fuel consumption in Nigeria and the energy ladder: A review of fuel wood use in Kaduna state. Journal of petroleum technology and alternative fuels 2013:Vol. 4(5):Pp. 85-9.

[55] Zaku, SG, Kabir, A, Tukur, AA, Jimento, JG, Woodfuel consumption in Nigeria and the energy ladder: A review of fuel wood use in Kaduna state. Journal of petroleum technology and alternative fuels 2013:Vol. 4(5):Pp. 85-9.

[56] FAO Global Forest Resources Assessment 2005 FAO forestry paper 147; progress towards sustainable forest management2005.

[57] Kituyi, E. Towards sustainable charcoal production and use: a systems approach. Proceedings of a regional workshop on wood fuel policy and legislation in Eastern and Southern Africa. RELMA, Nairobi, Kenya 2002.

[58] UNDP Energy assessment, United Nations Department of Economic and social affairs and world energy council, New York:UNDP 2002.

[59] Adedayo, $\mathrm{AF}$ (2005) Gender roles in forest resources utilization and its impact on rural environment in Kwara state, Nigeria:In Environmental sustainability conservation in Nigeria.

[60] Ogunsanwo, OY \&Ajala, 00, Firewood crisis in Lagos:implication on the suburban and rural ecosystem management: In JE, Abu, PO, Oni, L. Popoola(eds) Proceedings of the $28^{\text {th }}$ annual conference of Forestry Association of Nigeria held at Akure, Ondo state. Nov. $4^{\text {th }}-16^{\text {th }} 2002$ :Pp257-264.

[61] Zaku SG, Kabir, A, Tukur, AA, Jimento, IG Wood fuel consumption in Nigeria and the energy ladder:A review of fuelwood use in Kaduna state. Journal of petroleum technology and alternative fuels 2013:Vol. 4(5): Pp. 85-9..

[62] Zaku SG, Kabir, A, Tukur, AA, Jimento, IG Wood fuel consumption in Nigeria and the energy ladder: A review of fuelwood use in Kaduna state. Journal of petroleum technology and alternative fuels 2013:Vol. 4(5):Pp. 85-9.

[63] Fuwape, JA Heat of combustion of twenty savannah tree species. Proceedings of $15^{\text {th }}$ Annual conference, Forestry Association of Nigeria. In:Okojie, JA and 00, Okoro(eds) 1985:Pp. 70-79.

[64] APCU(1991) Report on Nigerian household energy study. Afforestation Programme Co-ordinating Unit(APCU). World Bank Project, Kano, Nigeria.

[65] APCU(1991) Report on Nigerian household energy study Afforestation Programme Co-ordinating Unit(APCU). World Bank project, Kano. Nigeria.

[66] Grutz, M, Cost-benefit analysis of fuelwood and forest protection projects in developing countries. Common wealth Forestry Review. 1987:66(1):225-29.

[67] Adegbehin, JO. \& Omijeh, JE A survey of fuelwood consumption and alternative sources of domestic energy in Kaduna state, Nigeria. Discovery and innovation, June, 1994. Vol. 6 No. 2.

[68] Adegbehin, JO \&Omijeh, JEA survey of fuelwood consumption and alternative sources of domestic energy in Kaduna state, Nigeria. Discoveryand Innovation. June, 1994. Vol. 6 No. 2.

[69] Zaku, SG, Kabir, A, Tukur, AA, Jimento, IG Wood fuel consumption in Nigeria and the energy ladder: A review of fuelwood use in Kaduna state. Journal of petroleum technology and alternative fuels 2013:vol. 4(5):Pp. 85-9. 
[70] Tukur, AL. (2015) Tragedy beyond the commons:livehood and Environmental changes in North-Eastern Nigeria. $21^{\text {st }}$ inaugural lecture held at Modibbo Adama University of Technology, Yola. December $2^{\text {nd }}$.

[71] Hillstrom, K, Hillstrom, JC Africa and the Middle East: A continental overview of Environmental issues. ABC-CLIO, Denver CO, USA, Oxford, UK. 2003.

[72] Olagunju, TE, Impacts of Human-induced deforestation, forest degradation and fragmentation on food security. New York, Science journal 2015a:8(1):4-16.

[73] FAO Global forest resources assessment-key findings. Food and Agricultural Organisation of the United Nations, Rome, 2006.

[74] Onyeanusi, AE \&Otegbeye, EY, Socio-economics. In:Agroforestry and land management practices diagnostic survey of Katsina state, Nigeria. In;Otegbeye, GO(ed)Katsina State Agricultural and Rural Development Authority, Katsina, 2002:Pp. 63-79.

[75] Olagunju, TE, Impacts of Human-induced deforestation, forest degradation and fragmentation of food security. New York. Science journal 2015b:8(1):4-16.

[76] UNCD, Desertification: A visual synthesis GRAPH 14. Press. Bresson, France, 2011:Pp. 1-52.

[77] Lester, RB, 2006. The earth is sinking: Advancing deserts and rising seas squeezing civilization. Earth Policy Institute. www. earthpolicy. org/update.

[78] Mohammed, D, Akpan, AE, Aliyu, HS, Role of community participation in combating desertification in the arid zone of Nigeria: An overview. Journal of Environmental Management 2013:3:49-58.

[79] Mohammed, D, Akpan, AE, Aliyu, HS, Role of community participation in combating desertification in the arid zone of Nigeria:An overview. Journal of Environmental Management2013:3:49-58.

[80] Nneji, LM, A review of the effects of desertification of food security. Rep. Opin. 2013: 5(10):27-33.

[81] Bullock, P, Lettouerou, H. (1994) Land degradation and desertification. Chapter 4 Pp. 1273-185.

[82] Bell, ML, Golberg, R, Hogrefe, G, Kinney, PL, Knowhop K. Lynn B. Climate change, ambient zone and health in 50 US cities. Climate change. 2007:82(1-2):61-76.

[83] Patz, JA Global climate change and everything infectious diseases. Journal of American Medical Association 1996:275(3):217-233.

[84] Cunningham, WP, Cunningham, M, Saigo, B. Environmental science: A global concern, New York. McGraw Hill. 2005.

[85] Betterton, C, Gadzama, NM Effects of drought on public health In:VO, Sagua et. al, (eds) Ecological disasters in Nigeria:Drought and desertification. Federal Ministry of Science and Technology, Lagos. 1987:pp 204-210.

[86] Kafaru, E. Immense help from nature. Workshop, Elikaf Health services Ltd. P212. 1994.

[87] Otegbeye, GO, Otegbeye, EY, Socio-economics. In:Agroforestry and land management practices. :Diagnostic. Survey of Katsina state, Nigeria. In:Otegbeye, GO(ed). Katsina State Agricultural and Rural Development Authority, Katsina 2002: Pp. 63-79.

[88] Olagunju, TE Forest transition:Towards modulating climate change. Nature science. 2015b:13(5):16-91.

[89] IPCC, Climate change:The IPCC scientific assessment: Cambridge University Press, Cambridge UK. 1990. Pp. 365.

[90] Sehgal, J. Abrol, JP, Soil degradationin India- status and impact transactions. 15 ${ }^{\text {th }}$ International Society of Soil Science. Acapulco, Mexico. 1994: 212 Pp.

[91] Jibrin, JMM, , Abubakar, SZ, Suleiman, A, Soil fertility status of the Kano River irrigation project area in the Sudan savannah, Nigeria. Journal of Applied science. 2008:8:692-696.

[92] Ajayi, SS, Fish and wildlife:In:Federal Environmental Protection Agency(FEPA) Nigerian Biodiversity and Action Plan. First draft, Abuja. The presidency, 1996.

[93] Musa JK, Saving Lake Chad. Proceedings of site roundtable. Libya, 17th December, 2008.

[94] Toye, 0, Desertification threatens economy, food security. Terra viva: the unofficial record of the United Nations World Summit of Sustainable Development. An IPS-interpress service independent publication, Johannesburg, South Africa, 26 $6^{\text {th }}$ August. issue, 2002. 
[95] Cunningham, WP, Cunningham, M, Saigo, B. Environmental science:A global concern. New York. Mc Graw Hill 2005.

[96] Toye, 0, Deserfication threatens economy, food security. Terra viva:the unofficial record of the United Nations Nations World Summit of Sustainable Development. An IPS-interpress service independent publication. Johannesburg, South Africa, 26 $6^{\text {th }}$ August, issue, 2002.

[97] Koohfken, AP Desertification, Drought and their consequences. Environment and Natural Resources Services (SDRN) FAO Research, Extension and Training Division 1996.

[98] Emodi, EE, Drought and desertification as they affect Nigerian Environment. Journal of Environmental Management. 2013:4(1):45-54.

[99] Pruit, D. \& Robin, J. Social conflict: Escalation, stalement and settlement. New York: Yale University Press1983.

[100] Deutsh, M. The resolution of conflict:constructive process. New Haven:Yale University Press, 1972.

[101] Ross, M, The culture of conflict. New Haven:Yale University Press, 1983.

[102] Cornet, A, Desertification and its relationship to the environment and development:a problem that affects us all. In: World Summit on Sustainable Development 2002.

[103] Pastemark, D, Schlissal, A, Combating desertification with plants. Springer, 2001:P 2015BN 978-0306-4668-8.

[104] Briassoulis, H, Policy intergration for complex environment problems: the example of Meditterranean desertification. Ashgate Publishing 2005. P16215BN978-0-7546-4243-5.

[105] Kabu, T. An overview of African wetlands: In: Wetlands Biodiversity and the Ramsar Convention: The role of the convention on wetlands in the conservation and wise use of Biodiversity:Hails A. (ed):Ramsar convention bureau land. Switzerland accessed on $6^{\text {th }}$ May, 2018.

[106] Kabu, T. An overview of African wetlands. In:Wetlands, Biodiversity and the Ramsar Convention: The role of the convention on wetlands in the conservation and wise use of Biodiversity:Hails A(ed):Ramsar convention bureau land Switzerland accessed on $6^{\text {th }}$ May, 2018.

[107] Hillstrom, K, Hillstrom, IC, Africa and the Middle East: A continental overview of Environmental issues. ABCCL10Denver CO, USA, Oxford, UK 2003.

[108] Lemly, AD, Kingsford, RT and Thompson, JR. Irrigated agriculture and wildlife conservation:conflict on a global scale. Environmental Management 2000:255:485-512.

[109] Akinola, OA, Ezealor, AU and Polet, G Conservation of waterbeds in the Hadejia-Nguru wetlands: current efforts and problems. Ostrich71, 1-2, 118-121.

[110] Abubakar, MM and Abubakar, JY, Some aspects of the limnology of Nguru lake, North western Nigeria. International Journal of Basic and Applied Sciences 2:, 140-144. 2013.

[111] Olofin, EA Dam-induced drying-out of the Hadejia-Ngure wetlands, Northern Nigeria and its implications for the fauna. In:Proceeding African crane and wetland training workshop 1993.

[112] Bird life international 2015 Important Birdlife Areas Fact sheet:Hadejia-Nguru wetlands. Cambridge, United Kingdom.

[113] MEA Millenium Ecosystem Assessment. Ecosystems and Human well being:synthesis. Washington DC Island Press.

[114] Gardinale, BJ Biodiversity loss and its impact on humanity. Nature2012:486:59-67.

[115] IUCN Species survival commission. IUCN Red categories and criteria (version 31) International Union for Conservation of Nature. 2012.

[116] IUCN International Union for Conservation of Nature. The IUCN Red list of threatened species (version 2013:2).

[117] Burkhard, B, Mapping ecosystem services, supply demand and budgets. Ecological indices2012:21:17-20.

[118] Burkhard, B, Mapping ecosystem services supply demand and budgets. Ecological indices 2012:21:17-20.

[119] Tallis, H. A global system for monitoring ecosystem services change. Bioscience 2012:62:977-986.

[120] Villamagna, AM Capacity, pressure, demand and flow: a conceptual framework for analysing ecosystem service provision and delivery. Ecological complex2013:15:114-121. 
[121] Maron, M, MGE Mitchell, Runting, RK, Rhodes, JR, Mace, GM, Keith, DA \& Watson, JEM. Towards a threat assessment framework for ecosystem services. Trends in Ecology \& Evolution. http//dx. doi. org/10. 1016/tree 2016. 12. 011. 2017. Elsevier Ltd.

[122] Russel, AE, Cambardella, Ca, Ewel, jj, Parkin, TB, Species rotation and life-form diversity effect on soil carbon in experimental tropical ecosystems. Ecological applications 2004:14(1):47-60.

[123] Paula M. Catterall, CP, Pollard, PC, Kanowski, J. F Recovery of soil properties and functions in different rain forest restoration pathways. Forest Ecology \& Management 2010:259(10):2083-2092.

[124] Naeem, S, Biodiversity and ecosystem functioning in restored ecosystems:extracting principles for a synthetic perspective, foundation of restoration ecology. Falk, DA(ed): Society for Ecological Restoration. International Island Press, 2006:210-237.

[125] Wright, JP, Symstad, AJ, Bullock, JM, Engelhardt, KAM, Jackson, IE, Benhardt, ES, Restoring biodiversity and ecosystem function: will an integrated approach improve results? Biodiversity ecosystem functioning and human well being. In:Naeem, S, Bunker DE, Hector, A. Loreau, MM, Perirings C. (eds) Oxford: Oxford University Press, 2009:167-177.

[126] Naeem, S, Biodiversity and ecosystem functioning in restored ecosystems:extracting principles for a synthetic perspective foundation of restoration ecology. Falk, DA(ed):Society for Ecological Restoration International Island Press, 2006:210-237.

[127] Adegbehin, J0, \& Omijeh, JE A survey of fuelwood consumption and alternative sources of domestic energy in Kaduna state of Nigeria. Discovery and Innovation, June1994:Vol. 6, No. 2.

[128] Alkali, S, SM, Maishanu and SC Bajpal(1990) Save fuelwood with improved woodstove: Danja experience Proceedings, National Forestry Workshop held by NAERLS/FRIN/FACU/FORMECU/FDF at FRIN, Ibadan, Nigeria. Pp 200-206.

[129] Repetto, R, Forest for trees:government policies and misuse of forest resources. World Resources Institute, Washington, DC1988.

[130] Aruofor, RO, 1986 An economic appraisal of pricing and tariff systems for Gmelina arborea, pulp wood and sawing in Nigeria. Msc thesis, Department of Forest Resources Management, University of Ibadan, Nigeria.

[131] Jackson, JK and Ojo, GOA, Productivity of natural wood land and plantations in the savannah region of Nigeria. Nigerian journal of Forestry, 1972:1(2):57-60.

[132] SPBK Electricity from the sunlights. Tungar-Buzu and Gotomo villages supplement on the solar energy centre. The Sokoto Polytechnic, Birnin-Kebbi, Sokoto state, Nigeria, 1991.

[133] KSN Report of the committee on alternative sources of energy. Kano state of Nigeria. 1989.

[134] Agbogidi, OM and AU, Ofuoku, Forestry extension: implications for forest protection. International journal of Biodiversity and Conservation 2009: Vol. 1 (5):Pp 98-104. 